\title{
Hubungan antara Body Image dengan Self Esteem pada Wanita Dewasa Muda Pasca Melahirkan di Jakarta Serta Tinjauannya dalam Islam
}

\section{Corelation Between Body Image and Self Esteem on Postpartum Young Adult Women in Jakarta and Its Islamic Review}

\author{
Khalida Ridwan; Zulfa Febriani; Siti Marhamah \\ Fakultas Psikologi, Universitas Yarsi, Jakarta 10510, Indonesia \\ Email:zulfa.febriani@yarsi.ac.id
}

KATA KUNCI KEYWORDS

ABSTRAK
Wanita dewasa muda pasca melahirkan, Body image, Self esteem Postpartum young adult women, Body image, Self esteem

Periode pasca melahirkan (post partum) adalah periode setelah kelahiran bayi dimana sang ibu menyesuaikan diri baik fisik maupun psikis. Selama periode itu, sebagian besar wanita memandang bentuk tubuh dan ukuran tubuhnya sebagai perubahan yang negatif. Hal ini mempengaruhi bagaimana para wanita dewasa muda pasca melahirkan mempersepsikan bentuk dan ukuran tubuhnya atau yang biasa disebut sebagai body image. Sementara itu, penerimaan dan penilaian body imagepositif atau negatif pada wanita dewasa muda pasca melahirkan berkaitan dengan self esteem, depresi pasca melahirkan, emosi yang negatif, dan juga perubahan interaksi sosial serta menimbulkan perilaku diet. Penelitian ini bertujuan untuk mengetahui hubungan antara body image dengan self esteem pada wanita pasca melahirkan. Sampel dipilih dengan teknik accidental sampling sebanyak 129 orang di Jakarta. Hasil korelasi dengan Pearson Product Moment menunjukkan bahwa terdapat hubungan positif yang signifikan antara body image dengan self esteem pada wanita dewasa muda pasca melahirkankan dengan $r=0,485$ dan nilai signifikansi $p=0,000(p>0,05)$. Penelitian selanjutnya dapat dilakukan dengan membandingkan berbagai latar belakang wanita paska melahirkan seperti pendidikan, status sosial ekonomi, kondisi kesehatan selama kehamilan, dan sebagainya.

Postpartum period is a period after delivering a baby which the mothers adapt either physically or psychologically. During the period, most women look at her body shape and size as a negative change. This affects how the young adult postpartum women perceive the shape and size of the body or referred to body image. Meanwhile, evaluation and acceptance of positive or negative body image in young adult women after childbirth related to self-esteem, postpartum depression, negative emotions, and also changes in social interactions and lead to dietary behavior. This study aimed to determine the relationship between body image and self-esteem in women after childbirth. 129 postpartum women in Jakarta are selected by accidental sampling technique. Corelation by 
Pearson Product Moment indicate that there is a significant positive relationship between body image and self-esteem in young adult women after childbirth, $r=0.485$ and significance value $p=0.000(p>0.05)$. More research are still needed to analyze the body image and self esteem of postpartum women in different background such as education, sosioeconomical status, health status during pregnancy, etc.

\section{PENDAHULUAN}

Masa kehamilan adalah salah satu tugas perkembangan yang didambakan oleh sebagian besar wanita yang telah memasuki kehidupan berumah tangga (Sari, 2009). Kehamilan dapat pula dikatakan sebagai ekspresi rasa perwujudan diri dan identitas sebagai wanita (Kaplan \& Sadock, dalam Rahmandani, Karyono \& Dewi, 2010), dan sebagai wujud femininitas seorang wanita (Widyanti, 2007). Akan tetapi, proses untuk menjadi seorang ibu adalah peristiwa yang mendebarkan dan penuh tantangan (Effendi \& Tjahjono, dalam Sari, 2009).

Kehamilan dan proses melahirkan menyebabkan terjadinya perubahan kondisi biologis dan psikologis seorang wanita, sehingga diperlukan beberapa penyesuaian (Hasni, Karini \& Andayani 2013). Selama kehamilan perempuan juga mengalami perubahan yang khas dalam segi fisik. Alexander dan Carlson (dalam Sari \& Siregar, 2012) menyatakan bahwa perubahan fisik meliputi payudara mengencang, sering buang air kecil, dan merasa lelah serta adanya kenaikan berat badan dan pembesaran pada bagian perut. Diketahui bahwa kenaikan berat badan yang ideal pada wanita selama kehamilan adalah sekitar 6,5-16,5 kg. Kenaikan berat badan di bawah ataupun di atas rentang tersebut menimbulkan masalah pada kesehatan ibu dan janin (Mochtar, dalam Sari, 2009).

Sikap terhadap berat dan bentuk tubuh selama kehamilan memiliki dampak penting terhadap kenaikan berat badan selama kehamilan dan kesehatan mental ibu setelah melahirkan (Rubin, dalam Sari, 2009). Sikap dan persepsi terhadap berat dan bentuk tubuh disebut juga sebagai body image (Cash dan Pruzinsky, dalam Warren \& Rio, 2012). Perubahan fisik selama kehamilan berkonsekuensi terhadap perubahan body image perempuan (Newman \& Newman, dalam Sari \& Siregar, 2012). Combes dan Schonveld (dalam Henderson \& Jones, 2006) mengidentifikasi bahwa selain khawatir tentang bagaimana mereka akan mengatasi nyeri proses melahirkan, ibu juga mengkhawatirkan tentang body image, terutama apakah mereka akan kembali ke bentuk tubuh mereka semula setelah melahirkan.

Kekhawatiran wanita akan body image dapat ditemukan dari hasil penelitian Fox dan Yamaguchi (dalam Sari, 2009) terhadap 76 wanita yang sedang hamil 30 minggu mengenai perasaan terhadap penampilan dan bentuk tubuh mereka. Hasilnya 67\% dari sampel yang sebelum hamil memiliki berat badan normal menyatakan adanya perubahan negatif terhadap body image mereka. Perubahan body image merupakan aspek kehamilan yang memerlukan waktu sebelum seorang wanita dapat beradaptasi. (Farrer, dalam Rahmandani, Karyono \& Dewi, 2010).

Puncak dari rangkaian proses emosional yang dialami wanita adalah proses melahirkan setelah sembilan bulan mengandung (Widyanti, 2007). Allah memberi wasiat pada manusia agar berbakti pada kedua orang tua karena proses persalinan yang dialami ibu merupakan suatu proses yang sangat berat. Pengaruh kontraksi rahim ketika bayi mau lahir, menyebabkan ibu merasakan sangat kesakitan, bahkan dalam keadaan tertentu, dapat menyebabkan kematian. Karena perjuangan ibu ketika melahirkan dan resiko yang sangat berat yang ditanggung seorang ibu, maka Allah memerintahkan kita untuk berbuat baik kepada orang tua (Jawas, 2003). Perintah 
ini terdapat dalam ayat Al-Qur'an yang artinya:

"Kami perintahkan kepada manusia supaya berbuat baik kepada dua orang ibu bapaknya, ibunya mengandungnya dengan susah payah, dan melahirkannya dengan susah payah (pula). mengandungnya sampai menyapihnya adalah tiga puluh bulan......." (QS. Al-Ahqaf 36:15).

Periode pasca melahirkan (post partum) adalah periode setelah kelahiran bayi atau persalinan, yaitu masa ketika sang ibu menyesuaikan diri baik fisik maupun psikis dengan proses pengasuhan anak. Periode ini berlangsung kira-kira selama enam minggu atau hingga tubuh melakukan penyesuaian diri ke keadaan yang dimiliki sebelum kehamilan (Santrock, 2005). Matlin (2004) menyatakan bahwa perubahan fisik yang terjadi pasca melahirkan juga berhubungan dengan bertambahnya ketidakpuasan terhadap tubuh pada wanita. Ketidakpuasan terhadap tubuh pada wanita ini dikarenakan kehamilan membawa perubahan pada ukuran dan bentuk tubuh yang mempengaruhi kondisi fisik yang tampak dari luar pada diri seorang ibu pasca melahirkan.

Stein dan Fairbun (dalam Jordan, Cadevila, \& Johnson, 2005) menjelaskan bahwa setelah melahirkan, tubuh jarang cepat kembali seperti bentuk tubuh sebelum melahirkan sehingga banyak wanita yang tidak siap dengan perubahan fisiknya. Hal ini didukung oleh penelitian yang dilakukan oleh Hisner (dalam Jordan, Cadevila, \& Johnson, 2005) yang mengemukakan bahwa $75 \%$ wanita dewasa muda pasca melahirkan gelisah akan berat badannya dan 75\% khawatir dengan kemungkinan tubuh mereka akan kembali normal seperti sebelum kehamilan. Terdapat penelitian lain oleh Fischman (Jordan, Cadevila, \& Johnson, 2005) yang menemukan bahwa $70 \%$ wanita tidak puas dengan tubuhnya enam bulan pasca melahirkan dan 39\% masih merasa tidak puas lebih dari satu tahun pasca melahirkan.

Perasaan tidak puas dengan tubuh mengindikasikan bahwa sebagian besar wanita memandang bentuk tubuh dan ukuran tubuhnya sebagai perubahan negatif, dan hal ini dapat mengakibatkan body image negatif (Gjerdingen, dkk., dalam Erbil, Senkul \& Basara, 2012). Body image negatif pada wanita dewasa muda pasca melahirkan menyebabkan menimbulkan keinginan untuk memiliki bentuk dan ukuran tubuh ideal yang menyebabkan perilaku diet. Perilaku diet yang dilakukan pada wanita dewasa muda pasca melahirkan berkontribusi pada perubahan fungsi tubuh wanita sehingga dapat mengakibatkan berkurangnya asupan nutrisi dan kalori serta menurunnya kualitas ASI (Erbil, Senkul \& Basara, 2012). ASI adalah ungkapan kasih sayang Allah sekaligus anugerah yang luar biasa terhadap setiap bayi yang terlahir ke muka bumi (Sunardi, 2008). Sebagaimana Allah menganjurkan para ibu untuk menyusui dalam surat AlBaqarah (2): 233 yang berbunyi:

"Dan ibu-ibu hendaklah menyusui anaknya dua tahun penuh, bagi yang ingin menyusui secara sempurna....".

Selain itu, body image negatif pada wanita dewasa muda pasca melahirkan juga mengakibatkan menurunnya self esteem (Erbil, Senkul \& Basara, 2012). Menurut Heatherton dan Wyland (2003) self esteem adalah sikap tentang diri dan berhubungan dengan keyakinan pribadi tentang keterampilan, kemampuan, hubungan sosial, dan hasil yang akan dicapai di masa depan. Standar nilai - nilai evaluasi individu tentang diri bisa positif atau negatif (Bordens dan Horowitz, 2008). Mereka yang memiliki harga diri yang tinggi diduga secara psikologis bahagia dan sehat (Branden, Taylor \& Brown, dalam Heatherton \& Wyland, 2003), sedangkan orang dengan harga diri yang rendah diyakini secara psikologis tertekan (Tennen \& Affleck, dalam Heatherton \& Wyland (2003).

Hasil penelitian yang dilakukan oleh Anisa Puspita Sari (2011) menunjukan bahwa terdapat hubungan antara citra tubuh terhadap harga diri pada ibu postpartum primipara di Puskesmas Mergangsa 
Yogyakarta. Hal ini membuat peneliti tertarik untuk melakukan penelitian yang serupa di wilayah Jakarta karena angka ibu melahirkan yang tinggi di Jakarta (lensaindonesia.com, 2011). Kondisi fisik, psikologis, dan tuntutan sosial yang dialami oleh wanita pasca melahirkan cenderung mempengaruhi self image mereka. Kondisi mereka juga diduga rentan terhadap masalah body image (Zahorick \& Weber, dalam Sari, 2011). Oleh karena itu, peneliti ingin mengetahui hubungan antara body image dengan self esteem pada wanita dewasa muda paska melahirkan di Jakarta.

\section{METODE}

Sampel penelitian ini adalah wanita dewasa pasca melahirkan berusia 20-40 tahun yang berlokasi di wilayah Jakarta sebanyak 129 subjek. Teknik sampling yang digunakan adalah accidental sampling.

Body image diukur dengan menggunakan kuesioner yang digunakan oleh Nirmala (1996). Alat ukur ini diadaptasi dari alat ukur body image yang dikembangkan oleh Thomas F. Cash pada tahun 1989 bernama Multidimensional Body-Self Relations Questionairre Appearance Scale (MBSRQ-AS) yang mengukur skala penampilan. Alat ukur ini terdiri dari 34 aitem yang mengacu pada lima aspek, yaitu appearance evaluation (evaluasi penampilan), appearance orientation (orientasi penampilan), body area satisfaction (kepuasaan terhadap bagian tubuh), overweight preocupation (kecemasan menjadi gemuk), dan selfclassified weight (pengkategorian ukuran tubuh). Semakin tinggi skor yang diperoleh maka dapat dikatakan bahwa subjek memiliki body image yang positif. Sebaliknya, semakin rendah skor yang diperoleh maka dapat dikatakan bahwa subjek memiliki body image yang negatif.

Self esteem diukur menggunakan The State Self Esteem Scale yang diadaptasi oleh peneliti berdasarkan skala yang dikembangkan oleh Heatherton dan Polivy (1991). Alat ukur ini terdiri dari 20 aitem.
Peneliti menggunakan adaptasi alat ukur dari Heatherton dan Polivy (1991) karena skala ini lebih spesifik mengukur tentang tiga komponen diantaranya performance (prestasi), social (sosial), dan physical (penampilan). Salah satu diantaranya berhubungan dalam mengukur self-esteem pada penelitian ini yaitu mengukur penampilan. Semakin tinggi skor yang diperoleh maka akan dapat dikatakan bahwa subjek memiliki self esteem tinggi. Demikian pula sebaliknya, semakin rendah skor yang diperoleh maka akan dapat dikatakan bahwa subjek memiliki self esteem rendah.

$M B S R Q-A S$ yang peneliti gunakan memiliki reliabilitas dengan teknik Croanbach's Alpha sebesar 0,823 dan aitem yang digunakan hanya 25 . Sembilan aitem gugur karena memiliki validitas aitem $<0,2$ (Nisfiannoor, 2009). The State Self Esteem Scale yang peneliti gunakan memiliki reliabilitas dengan teknik Croanbach's Alpha sebesar 0,858 dan aitem yang digunakan hanya 19. Satu aitem gugur karena memiliki validitas aitem $<0,2$ (Nisfiannoor, 2009). Dengan indeks reliabilitas tersebut maka $M B S R Q-A S$ dan The State Self Esteem Scale yang digunakan peneliti menunjukkan reliabilitas yang baik $(\mathrm{r}>0,7)$ (Azwar, 2004).

\section{HASIL DAN ANALISIS}

Melalui profil demografis subjek, dapat diketahui bahwa dari 129 subjek penelitian mayoritas subjek yang terlibat dalam penelitian berada dalam rentang usia 26 - 30 tahun sebanyak $40 \%$, berada dalam rentang waktu $0-3$ bulan setelah melahirkan sebanyak $46 \%$, melahirkan secara normal sebanyak $66 \%$, berada di Jakarta Pusat sebanyak 24\%, berpendidikan terakhir S1 sebanyak 46\%. Selain itu, sebagian besar subjek memiliki berat badan $51-60 \mathrm{~kg}$ sebanyak 34\%, mengalami kenaikan berat badan $6-16 \mathrm{~kg}$ sebanyak $48 \%$, dengan tinggi badan $151-160 \mathrm{~cm}$ sebanyak 62\%, memiliki anak satu sebanyak $60 \%$, dan dengan pendapatan 
keluarga sebesar $>$ Rp 5.000.000 sebanyak $50 \%$.

Tabel 1. Mean, standar deviasi, nilai max, dan nilai min

\begin{tabular}{cccccc}
\hline Alat Ukur & Mean & SD & Max & Min & N \\
\hline Body Image & 66,16 & 7,585 & 92 & 44 & 129 \\
Self Esteem & 53,06 & 6,450 & 72 & 35 & 129 \\
\hline
\end{tabular}

Berdasarkan tabel 1, nilai mean pada alat ukur body image sebesar 66,16, standar deviasi 7,585 , nilai $\max 92$, nilai min 44, dan jumlah peserta 129 subjek. Sedangkan, nilai mean pada alat ukur self esteem sebesar 53,06, standar deviasi 6,450, nilai max 72 dan nilai 35 , dan jumlah peserta 129 subjek.

Pengkategorisasian body image dan self esteem pada tabel 2 didapat dengan menghitung skor ideal yakni kategorisasi berdasarkan skor ideal yang telah ditetapkan terlebih dahulu (Azwar, 2004). Kategorisasi subjek dapat dilihat pada tabel 2 berikut ini:

Tabel 2. Kategorisasi body image dan self esteem

\begin{tabular}{ccccc}
\hline $\begin{array}{c}\text { Alat } \\
\text { Ukur }\end{array}$ & Kategori & $\begin{array}{c}\text { Rumus } \\
\text { Norma }\end{array}$ & Frekuensi Persentase \\
\hline Body & Negatif & $25 \leq \mathrm{x} \leq 63,5$ & 43 & $33 \%$ \\
Image & Positif & $\mathrm{x}>63,5$ & 86 & $67 \%$ \\
& & & & \\
Self & Rendah & $19 \leq \mathrm{x} \leq 47,5$ & 22 & $17 \%$ \\
Esteem & Tinggi & $\mathrm{x}>47,5$ & 107 & $83 \%$ \\
\hline
\end{tabular}

Sebanyak 43 subjek penelitian (33\%) memiliki body image negatif dan sebanyak 86 subjek penelitian (67\%) memiliki body image positif. Alat ukur self esteem sebanyak 22 subjek penelitian (17\%) memiliki self esteem rendah dan sebanyak 107 subjek penelitian (83\%) memiliki self esteem tinggi.

Berdasarkan hasil uji normalitas menggunakan one-sample KolmogorofSmirnov Test, nilai sig pada body image sebesar $1.080>0.05$ dan nilai sig pada self esteem sebesar $0.194>0.05$. Hasil ini menandakan data dalam penelitian berdistribusi dengan normal. Dengan demikian, uji hipotesis menggunakan metode pearson product moment.
Hasil korelasi antara body image dengan self esteem pada wanita dewasa muda paska melahirkan dapat dilihat pada tabel 4.

\begin{tabular}{|ccc|}
\hline Tabel 4. Hasil korelasi Pearson Product Moment \\
\hline Variabel & $\begin{array}{c}\text { Perason } \\
\text { Correlation }\end{array}$ & $\begin{array}{c}\text { Sig. (2 } \\
\text { tailed) }\end{array}$ \\
\hline $\begin{array}{c}\text { Body Image dan } \\
\text { Self Esteem }\end{array}$ & 0,485 & 0,000 \\
\hline
\end{tabular}

Nilai koefisien korelasi antara body image dan self esteem pada wanita dewasa muda pasca melahirkan sebesar 0.485, dengan tingkat signifikan $0.000(<0.05)$. Nilai $\mathrm{r}=0.485$, menunjukkan hubungan kedua variable memiliki keeratan sedang (Sugiyono, 2011). Dengan begitu dapat dikatakan bahwa terdapat hubungan yang signifikan antara body image dengan self esteem pada wanita dewasa muda pasca melahirkan.

\section{DISKUSI}

Hasil dari penelitian ini adalah terdapat hubungan yang signifikan antara body image dengan self esteem pada wanita dewasa muda pasca melahirkan. Hubungan yang dimiliki bersifat positif antara body image dengan self esteem pada wanita dewasa muda pasca melahirkan. Hal ini dapat dilihat dari koefisien korelasi yang sebesar $r=0,485(p<0,05)$. Nilai koefisien korelasi yang sebesar $\mathrm{r}=0,485$ memiliki keeratan sedang antar variabel body image dan self esteem (Sugiyono, 2011). Mengacu pada hasil analisis tersebut, hipotesis penelitian yang menyatakan bahwa "terdapat hubungan yang signifikan antara body image dengan self esteem pada wanita dewasa muda pasca melahirkan" dapat diterima.

Hasil penelitian ini sejalan dengan penelitian Sari (2011) pada 60 subjek ibu postpartum primipara (melahirkan pertama kali) dengan usia maksimal 30 tahun. Sari (2011) menyatakan bahwa terdapat hubungan antara citra tubuh dengan harga diri pada ibu postpartum primipara di Puskesmas Mergangsa Yogyakarta, dengan hasil nilai koefisien korelasi sebesar $\mathrm{r}=$ 0,302 dan signifikan $p=0,019$. 
Berdasarkan hasil kategorisasi body image dalam penelitian ini, terdapat 33\% subjek pada wanita dewasa muda pasca melahirkan memiliki body image negatif dan sebanyak $67 \%$ subjek pada wanita dewasa muda pasca melahirkan memiliki body image positif. Berdasarkan hasil kategorisasi self esteem dalam penelitian ini, terdapat $17 \%$ subjek pada wanita dewasa muda pasca melahirkan memiliki self esteem rendah dan sebanyak 83\% subjek pada wanita dewasa muda pasca melahirkan memiliki self esteem tinggi. Dengan demikian, mayoritas subjek memiliki body image positif dan self esteem tinggi. Hal ini sejalan dengan penelitian Sari (2011) yang menemukan bahwa mayoritas subjek sebayak 53,3\% memiliki self esteem tinggi. Selain itu, penelitian oleh US Departement of Health and Service (dalam Yanti, 2014) menyatakan bahwa satu dari empat wanita yang melahirkan melalui pembedahan caesar merasakan kehilangan otonomi dan penurunan self esteem. Namun pada penelitian ini, mayoritas subjek melalui proses melahirkan secara normal sebanyak 85 orang (66\%).

Berdasarkan kenaikan berat badan sebelum melahirkan, 62 orang (48\%). mengalami kenaikan berat badan $6-16 \mathrm{~kg}$ yang masih tergolong ideal selama kehamilan (Mochtar, dalam Sari, 2009). Tergambar lagi dari keluhan yang dialami subjek selama kehamilan adalah keluhan kehamilan biasa yaitu sering merasa mual atau morning sickness 46 orang (36\%). Hampir semua kehamilan pada bulan pertama ditandai dengan munculnya rasa mual dan biasanya sulit ditahan dan datangnya sesaat-sesaat. Rasa mual ini muncul karena adanya peningkatan hormonal dan akan menghilang pada trimester pertama pada kehamilan (Apriani, 2007).

Sebagian besar subjek memiliki pendapatan keluarga sebesar $>\mathrm{Rp}$ 5.000.000 ditemukan sebanyak 65 orang (50\%). Hanya 8 orang $(6 \%)$ yang pendapatannya kurang dari Rp 1.500 .000 dan sisanya berada pada rentang pendapatan Rp 1.500.000 - 5.000.000. Data Badan Pusat Statistik (BPS) (dalam Heriawan, 2010) menyatakan bahwa total karyawan atau pekerja di Indonesia yang berpenghasilan $>$ Rp 5.000.000/bulan tergolong pada golongan atas. Ort, Robins, dan Trzesniewski (2010) menyatakan bahwa status sosial ekonomi merupakan salah satu faktor yang mempengaruhi self esteem. Status sosial ekonomi dapat mempengaruhi self esteem karena status dan kekayaan dapat mempengaruhi persepsi seseorang tentang nilai pada dirinya. Selama masa dewasa, individu semakin menempati posisi kekuasaan dan status, yang mungkin menampilkan perasaan self esteem (Dannefer, Gove, Ortega, Style, Helson, Mitchell, \& Moane, dalam Ort, Robins, \& Trzesniewski, 2010). Meskipun pada penelitian ini mayoritas subjek memiliki self esteem tinggi dan berpendapatan cukup baik, peran status sosial ekonomi terhadap self esteem subjek tidak dibandingkan lebih lanjut karena proporsi subjek dalam status sosial ekonomi tidak seimbang.

Peneliti meminta subjek untuk memberikan penilaian subjektif mereka terhadap kepuasan hubungan dengan pasangan dan keluarga secara memberi rating dari 1 (sangat tidak memuaskan) hingga 10 (sangat memuaskan). Sebagian besar subjek berjumlah 96 orang $(73,8 \%)$ merasa puas terhadap hubungannya dengan keluarga. Dari 96 orang tersebut, semuanya memiliki self esteem yang tinggi dan 65 orang memiliki body image positif. Dalam hal kepuasan hubungan dengan pasangan, sebanyak 102 orang $(79 \%)$ merasa puas terhadap hubungannya dengan pasangan. Dari 102 orang tersebut, semuanya memiliki self esteem yang tinggi dan sebanyak 69 orang memiliki body image positif. Artinya, sebagian besar subjek penelitian ini memiliki hubungan yang baik dengan pasangan dan keluarga meskipun tidak diteliti lebih lanjut peranan hubungan tersebut terhadap body image dan self esteem subjek. Hubungan yang baik dengan keluarga dan pasangan dapat menjadi 
bentuk dukungan sosial yang termasuk dalam faktor-faktor yang mempengaruhi body image (Cash dan Pruzinsky, 2002) dan self esteem (Monks, 2004). Sejalan dengan Taylor (dalam Widyanti, 2007) bahwa dukungan sosial dapat berasal dari keluarga, pasangan, teman sekerja dan teman di lingkungan sekitar. Seseorang yang memiliki dukungan sosial yang tinggi mengalami hal yang positif dalam kehidupannya, mempunyai harga diri yang lebih tinggi dan berpandangan lebih optimis terhadap kehidupannya dibandingkan mereka yang memiliki dukungan sosial yang rendah. Hasil penelitian Fatimah (2009) juga menunjukkan bahwa adanya hubungan dukungan suami dengan kejadian postpartum blues pada Ibu primipara di ruang Bugenvile RSUD Tugurejo Semarang. Hasil tersebut menunjukkan perlunya dukungan suami yang lebih kepada istri setelah melahirkan untuk mencegah gejala postpartum blues pada wanita.

Ada beberapa hal yang perlu diperhatikan untuk penelitian serupa ke depannya. Pertama, penelitian ini menggunakan teknik incidental sampling sehingga proporsi populasinya tidak sama untuk menjadi sampel dan tidak dapat digeneralisasi untuk seleuruh wilayah Jakarta. Kedua, wanita postpartum dalam penelitian ini terdata dengan jumlah anak (kelahiran pertama, dua, dan seterusnya) namun peneliti tidak mengontrol apakah pengalaman kelahiran ini juga berperan terhadap body image dan self esteem subjek. Selain itu, gambaran keadaan partisipan secara umum terkait status sosial ekonomi yang telah dipaparkan di atas tidak dibandingkan lebih lanjut karena distribusinya tidak proporsional. Profil lain seperti rentang waktu paska melahirkan, kenaikan berat badan yang dialami dan kondisi berat badan saat ini juga tidak diperbandingkan apakah membedakan atau berperan terhadap body image dan self esteem wanita postpartum.

Dalam Islam, manusia telah diciptakan oleh Allah SWT dalam bentuk yang paling sempurna dan sebaik-baiknya. Hal ini tertuang dalam surat At-Tin (95) ayat 4 yang berarti: "Aku telah menciptakan manusia dalam sebaik-baik bentuk". ArRaghib Al-Asfahani, seorang pakar bahasa Al-Qur'an menyebutkan bahwa kata 'taqwiim' pada ayat ini merupakan isyarat tentang keistimewaan manusia dibanding binatang, yaitu dengan dikaruniai akal, pemahaman, dan bentuk fisik yang tegak dan lurus. Jadi 'ahsani taqwiim' berarti bentuk fisik dan psikis yang sebaikbaiknya. Keyakinan seperti ini harus ditanamkan dalam diri manusia untuk menciptakan body image yang baik.

Sejak awal mula penciptaan dunia, Allah SWT menciptakan segala sesuatunya dalam keanekaragaman. Tubuh manusia pun terdiri dari anggota-anggota tubuh yang berbeda baik sifat maupun fungsinya. Hal itu merupakan tanda-tanda kekuasaan Allah sebagaimana Allah berfirman:

"Dan di antara tanda-tanda kekuasaan-Nya ialah menciptakan langit dan bumi dan berlain-lainan bahasamu dan warna kulitmu. Sesungguhnya pada yang demikian itu benar-benar terdapat tanda-tanda bagi orang-orang yang mengetahui”. (QS. ArRum 30:22).

Oleh sebab itu, manusia tidak perlu untuk mengubahnya karena dalam keanekaragaman itu kemuliaan, keindahan dan kebesaran Allah SWT semakin terlihat.

Manusia adalah makhluk paling indah dan paling sempurna yang telah Allah SWT ciptakan dibandingkan dengan makhluk Allah lainnya yang ada di bumi ini. Hal ini dikarenakan dalam diri manusia terdapat bermacam keindahan dan keunikan lain yang dapat diamati melalui penelitian ilmiah, seperti susunan kromosom, sel, dan sebagainya. Hal ini termuat dalam firmanNya di QS. Al-Infithar ayat 6-8

"Hai manusia, apakah yang telah memperdayakan kamu (berbuat durhaka) terhadap Rabbmu Yang Maha Pemurah. Yang telah menciptakan kamu lalu menyempurnakan kejadianmu dan menjadikan (susunan tubuh) mu seimbang, dalam bentuk apa saja yang Dia kehendaki, Dia menyusun tubuhmu." 
Dengan demikian, manusia diperintahkan oleh Allah untuk senantiasa bersyukur sehingga menumbuhkan sikap dan persepsi yang positif terhadap tubuh (body image yang positif). Orang yang dipenuhi rasa syukur akan terbawa pada kehidupan yang lebih sehat, lebih positif sepanjang hari sehingga akan terhindar dari kebiasaan memendam pikiran-pikiran negatif. Tidak perlu merasa cemas oleh bentuk tubuh yang menarik berdasarkan pendapat media atau orang lain. Dalam Islam tiada perbedaan manusia berdasarkan kecantikan atau ketampanan seseorang, atau lain-lain kecuali hanya amal sebagaimana yang disabdakan Rasulullah SAW,

"Sesungguhnya Allah tidak melihat kepada bentuk, rupa, dan harta benda kalian, tetapi Allah memperhatikan hati dan amal-amal kalian". (HR. Muslim).

Self-esteem merupakan salah satu sifat dan norma moral utama yang dibawa oleh Islam yang dikenal dengan akhlak. Kesadaran self-esteem akan tampak dalam sikap menuntut kebaikan dan menjauhi kejahatan, berpegang pada sifat-sifat kesatriaan dan cita-cita yang tinggi dan luhur, bebas dari pengaruh hawa nafsu dan tidak terbelenggu oleh syahwat-syahwat duniawi, tidak tersilau oleh kemegahankemegahan dan pangkat-pangkat yang kosong. Sifat-sifat yang demikian itulah yang mengangkat manusia ke tingkat yang layak sebagai makhluk Allah SWT yang termulia, sedang sifat-sifat dan tingkah laku yang bertentangan dengan sifat tersebut akan menurunkan derajat manusia dari tingkatnya yang termulia ke tingkat makhluk-makhluk Allah SWT yang rendah (Mahmud, 1996).

Perubahan fisik yang terjadi pasca melahirkan juga berhubungan dengan bertambahnya ketidakpuasan terhadap tubuh pada wanita. Ketidakpuasan terhadap tubuh pada wanita ini dikarenakan kehamilan membawa perubahan pada ukuran dan bentuk tubuh yang mempengaruhi kondisi fisik yang tampak dari luar pada diri seorang ibu pasca melahirkan (Matlin, 2004). Sedangkan kita sebagai umat Muslim harus mensyukuri segala nikmat yang diberikan oleh Allah SWT. Rasa syukur yang dimiliki oleh wanita dewasa muda pasca melahirkan dengan menerima segala bentuk yang berbeda-beda antara satu dengan yang lainnya serta menyayangi diri sendiri atas tindakan dan pemikirannya akan mempengaruhi body image dan self esteem. Kehamilan dan persalinan juga memberikan kedudukan yang mulia kepada wanita sehingga Allah SWT dan Rasulullah SAW memerintahkan manusia untuk menghormati dan berbuat baik kepada orang tuanya sebagaimana firman Allah Ta'ala:

"Kami perintahkan kepada manusia supaya berbuat baik kepada dua orang ibu bapaknya, ibunya mengandungnya dengan susah payah, dan melahirkannya dengan susah payah (pula). Mengandungnya sampai menyapihnya adalah tiga puluh bulan, sehingga apabila dia telah dewasa dan umurnya sampai empat puluh tahun ia berdoa: "Ya Tuhanku, tunjukilah aku untuk mensyukuri nikmat Engkau yang telah Engkau berikan kepadaku dan kepada ibu bapakku dan supaya aku dapat berbuat amal yang saleh yang Engkau ridhai; berilah kebaikan kepadaku dengan (memberi kebaikan) kepada anak cucuku. Sesungguhnya aku bertaubat kepada Engkau dan sesungguhnya aku termasuk orang-orang yang berserah diri". (QS. Al-Ahqaf 36:15).

Dengan demikian, tidak sepatutnya wanita postpartum memiliki body image negatif dan self esteem rendah padahal ia telah dianugerahi kesempatan oleh Allah SWT untuk hamil dan melahirkan, sehingga mendapatkan keutamaan, amal bakti dan doa dari keturunanya.

Rasulullah SAW mengajarkan lewat doa ketika bercermin, yang artinya "Ya Allah, (sebagaimana) engkau membaguskan rupaku, baguskanlah pula akhlakku". (HR. Baihaqi). Setidaknya terdapat empat makna penting dari doa bercermin ini (Hariyadi, 2013), diantaranya: Kesadaran bahwa tubuh dan penampilan 
adalah pemberian Allah; rasa syukur telah diberi oleh Allah atas fisik yang sempurna; kesadaran bahwa fisik atau tubuh hanyalah "wadah" dan bukan esensi; permohonan kepada Allah agar diberi akhlak yang baik sebagai esensi tubuh yang telah diberikan. Kandungan dari doa tersebut mengartikan bahwa apapun bentuk rupa yang telah diberikan oleh Allah SWT merupakan hal yang paling baik. Oleh sebab itu, seorang muslim hendaknya selalu bersyukur atas segala pemberian Allah SWT termasuk fisik yang dimiliki sehingga dapat menimbulkan body image yang positif di dalam dirinya. Ketika seorang muslim sudah bersyukur atas apa yang dimilikinya ia akan memiliki harga diri yang tinggi pula.

\section{SIMPULAN}

Hasil dari penelitian ini adalah terdapat hubungan yang signifikan antara body image dengan self esteem pada wanita dewasa muda pasca melahirkan. Hubungan yang dimiliki bersifat positif antara body image dengan self esteem pada wanita dewasa muda pasca melahirkan. Hal ini dapat dilihat dari koefisien korelasi yang sebesar $r=0,485$ serta taraf signifikansi sebesar $p=0,000(p<0,05)$. Nilai koefisien korelasi yang sebesar $\mathrm{r}=0,485$ memiliki keeratan sedang antar variabel body image dan self esteem (Sugiyono, 2011). Hipotesis penelitian yang menyatakan bahwa "terdapat hubungan yang signifikan antara body image dengan self esteem pada wanita dewasa muda pasca melahirkan" dapat diterima.

Dengan demikian, dapat dikatakan bahwa ketika seorang wanita dewasa muda pasca melahirkan memiliki body image yang positif maka self esteem pun akan tinggi, dan sebaliknya jika seorang wanita dewasa muda pasca melahirkan memiliki body image yang negatif maka self esteem pun akan rendah.

Allah telah menciptakan manusia dengan sebaik-baik bentuk meskipun dalam keanekaragaman rupa dan warna. Hal itu merupakan tanda kekuasaan Allah agar manusia senantiasa bersyukur sehingga memunculkan body image yang positif. Di samping itu, manusia merupakan makhluk yang paling mulia di sisi Allah bukan karena rupa namun karena kelebihan akal yang dimiliki dan akhlak (perilaku yang baik). Hal ini menunjukkan bahwa sebagai orang Islam sudah sepatutnya bersyukur dan tidak rendah diri hanya karena perubahan bentuk tubuh yang tidak diinginkan.

\section{SARAN}

Beberapa saran yang dapat diberikan berdsarkan penelitian yang telah dilakukan, adalah:

1. Penelitian berikutnya perlu memperhatikan komposisi sampel dengan teknik pengambilan sampel yang lebih proporsional.

2. Penelitian berikutnya disarankan untuk melakukan analisis yang lebih mendalam melalui perbandinganperbandingan aspek-aspek profil subjek seperti, latar belakang sosial ekonomi, kondisi kehamilan yang dijalani, dukungan sosial yang diterima, rentang waktu paska melahirkan, kenaikan berat badan yang dialami, kondisi berat badan saat ini dan factor-faktor lain yang mungkin terkait.

3. Peneliti juga perlu melakukan kontrol dan perbandingan antara body image dan self esteem berdasarkan periode postpartum yang dialami.

\section{DAFTAR PUSTAKA}

Al-Qur'an Al-Karim dan Terjemahannya Al-Hadits

Apriani, L. (2007). Keluhan subjektif ibu hamil trimester I di kelurahan Indra Kasih kecamatan Medan Tembung bulan September. Naskah Publikasi Program D IV Bidan Pendidikan Fakultas Kedokteran Universitas Sumatera Utara, Medan.

Azwar, S. (2004). Penyusunan skala pikologi. Yogyakarta: Pustaka Pelajar. 
Bordens, Kenneth S., \& Horowitz, Irwan A. (2008). Social psychology. Princeton University Press.

Erbil, N., Senkul, A., \& Basara, G. F. (2012). Body Image among Turkish women during The first year postpartum. Health Care Women International. 33 (2) : 12537.

Fatimah, S. (2009). Hubungan dukungan suami dengan kejadian postpartum blues pada ibu primipara di ruang Bugenvile RSUD Tugurejo Semarang. Jurnal Program Studi Ilmu Keperawatan Fakultas Kedokteran Universitas Diponegoro, Semarang.

Hasni, N. I., Karini, S. M., \& Andayani, T. R. (2013). Hubungan antara citra tubuh saat hamil dan kestabilan emosi dengan postpartum blues di Puskesmas Grogol Sukoharjo. Jurnal Fakultas Kedokteran Universitas Sebelas Maret

Heatherton, T. F., \& Polivy, J. (1991). Development and validation of a scale for measuring state Self-Esteem. Journal of Personality and Social Psychology, 60, 895-910.

Heatherton, T.F, dan Wyland, C. (2003). Assesing self eteem. In S. Lopez dan R. Synder, (Eds). Assesing positive psychology. (pp. 219-233). Washington, DC: APA.

Henderson, C., \& Jones, K. (2006). Buku ajar konsep kebidanan. Jakarta: Buku Kedokteran EGC

Jawas, Y.A.Q. (2003). Birrul walidain berbakti kepada kedua orang tua. Jakarta: Pustaka Al-Taqwa.

Jordan, K., Cadevila, R., dan Johnson, S. (2005). Baby or beauty: A Q study into post pregnancy body image. Journal of Reproductive and Infant Psychology. 23 (1): 19-31.

Matlin, A. W. (2004). Psychosocial adaptation in pregnancy. New Jersey: Prentice Hall

Monks. (2004). Psikologi Perkembangan: Pengantar dalam berbagai bagiannya. Jakarta: Penerbit Erlangga.

Nisfiannoor, M. (2009). Pendekatan statistika modern untuk ilmu sosial. Jakarta: Salemba Humanika.

Rahmandani, A., Karyono., dan Dewi, E. K. (2010). Strategi penanggulangan (coping) pada ibu yang mengalami postpartum blues di rumah sakit umum daerah kota Semarang. Jurnal Fakutas Psikologi Universitas Diponegoro.

Santrock, J. W. (2005). Life-span development. USA: McGraw-Hill Humanities Social.

Sari, A. P. (2011). Hubungan antara citra tubuh terhadap harga diri pada ibu postpartum primipara di Puskesmas Mergangsan Yogyakarta. Jurnal Program Studi Ilmu Keperawatan Fakultas Kedokteran dan Ilmu Kesehatan Universitas Muhammadiyah Yogyakarta.

Sari, D. N. (2012). Hubungan antara body image dan self esteem pada dewasa awal tuna daksa. Jurnal Fakultas Psikolgi Universitas Surabaya.

Sari, S. H. (2009). Pengaruh body image terhadap penyesuaian diri wanita pada kehamilan pertama. Naskah Puslikasi Program Studi Psikologi Fakultas Psikologi Universitas Sumatera Utara.

Sari, S. H., \& Siregar, A. R. (2012). Peran body image terhadap penyesuaian diri perempuan dewasa dini pada kehamilan pertama. Jurnal Fakultas Psikologi Universitas Sumatera Utara.

Sugiyono. (2011). Statistika untuk penelitian. Bandung: Alfabeta.

Sunardi. (2008). Ayah beri aku ASI. Solo: Aqwamedika

Warren, C. S. \& Rio, R. M. (2012). The relationship among acculturation, acculturative stress, endorsement of western media, social comparison, and body image in Hispanic male college student. Journal of American Psychological Association. Vol.14, No.2, 192-201.

Widyanti, Y. R. (2007). Hubungan natara dukungan sosial suami dengan depresi istri setelah kelahiran anak pertama. Naskah Publikasi Fakultas Psikologi Universitas Katolik Soegijapranata, Semarang

Yanti, N. P., (2014). Gambaran kebahagiaan pada wanita yang melahirkan melalui pembedahan caesar dengan alasan medis (dibandingkan dengan wanita yang melahirkan alami). Naskah Pusblikasi Program Studi Psikologi Fakultas Psikologi Universitas Indonesia, Jakarta. 